\title{
Chapter 9. Dover Street to Dixie and the Politics of Cultural Transfer and Exchange
}

\section{David Linton and Len Platt}

\author{
From Dover Street to Dixie, \\ We're taking Mr Gay, \\ There we shall see the old Plantation, \\ Down in U.S.A. \\ There we shall see the dear old Cabin, \\ With roses around the door, \\ That's where we'll meet our coal black mammy, \\ Coal black mammy once more!
}

Dover Street to Dixie (1923)

The eagerly awaited revue Dover Street to Dixie opened in May 1923 at the Pavilion Theatre in London. Split into two parts, the first half - the Dover Street sectionfeatured an all-white British cast, including Stanley Lupino. The second half, the cause of all the anticipation and controversy, was performed by African-Americans from the late-night New York cabaret plantation revue Nighttime Frolics in Dixieland (1922). Will Vodery, musical director and arranger of Florenz Ziegfeld's plantation revues, led the orchestra for this part of the show, which featured Florence Mills.

Mills had been at the heart of the groundbreaking Shuffle Along (1921), vividly described by Langston Hughes as 'a honey of a show. Swift, bright, funny, rollicking, and gay, with a dozen danceable, singable tunes....it gave just the proper 
push - a pre-Charleston kick - to that Negro vogue of the 20's, that spread to books, African sculpture, music, and dancing., ${ }^{1}$ Dover Street to Dixie, produced by C. B. Cochran, one of six shows he was simultaneously working on, was a vehicle for Mill's emergence as an international star. ${ }^{2}$ According to her biographer, Bill Egan, 'Harlemites' of the 1920s saw the engagement in terms that went well beyond personal achievement, 'greeting Florence's engagement to perform overseas as a compliment to her race' ${ }^{3}$

The new show may have seemed a hotchpotch, even by revue standards, combining the travel narrative, traditional in late-nineteenth and early-twentieth century musical theatre, with all the contemporaneity of African-American performance, characterised by jazz styling and ragtime. In fact, there were strong structural links and patterns across the piece. The first part, the 'white half', took a narratological stance on the jazz age, constructing modernity in familiar terms as comic disorder, a world of dissipated bright young things, 'jazz jugglers—-saxophone syncopaters - hurrying, scurrying, worrying', whose main activity in life is dancing. 'We've been dancing all the evening', they exclaim,

At different cabarets.

We find it better exercise,

Than watching pictures or,

Those silly problem plays.

We're sick of golf and tennis,

We never touch a card.

We'd gladly dance a hundred miles,

But hate to walk a yard. ${ }^{4}$ 
Set at the heart of the modern metropolis, Dover Street to Dixie opened with a group of fashion-conscious revellers leaving a trail of night clubs behind and looking for yet more fun. Here was London in what would become known as the 'jazz age', asserting its contemporaneity through a dance and music culture where 'London's rich and privileged upper classes reconstituted themselves along more glamorous American lines'.5 'Jazz me to Bruton Street, Freddie,' asks a lively young flapper, 'if it's not out of your way.' 'No trouble', replies Freddie, 'I can Tango back to the club afterwards. $^{, 6}$

At the same time, the modern world in Dover Street to Dixie finds itself in an uncertain condition, framed by nostalgia and insecurity. The show registers a series of traditional signifiers of England in decline-distressed aristocrats selling off family antiques to a nouveau riche that earns its fortunes from such modern, soft and plastic commodities as 'plasticene'; cheeky jumped-up cockneys who no longer know their place and the plangent strains of an 'old-time waltz' playing in the ballroom of Lady Walbeck's fashionable London house in Dover Street. ${ }^{7}$ The setting is itself emblematic of a certain ambiguity, an evocation of both refined tradition and the hustle and bustle of contemporary urban life. Dover Street, off Piccadilly, was originally residential, the work of a seventeenth-century syndicate of aristocratic developers responsible for other eminently desirable addresses in central LondonBond Street and Albemarle Street. By the end of the nineteenth century, however, Dover Street had become a much a livelier place. Surrounded by all the glamour of club land, it was distinctly 'ritzy', a status it continued to hold into the 1920s and beyond.

The central narratological figure in the show is a strange old man, a 'Georgian ...gentleman clad in garments of 200 years ago', who emerges mysteriously from a 
hole in the ground at the beginning of the show. 'As I journeyed homewards from the Tavern last night, somewhat unsteadily', he explains, 'I fear I must have stumbled into this excavation and thus was laid low in a stupor'. This unnamed figure has no idea where he is. The cockney night watchman, struggling to understand the stranger's style of talking, thinks he must be a 'blinking foreigner', an insult that produces immediate, unequivocal rebuttal. 'Sir, I am a loyal subject of King George the First.' Here, then, the confusion is at least partly explained. The old gentleman, later revealed to be no less a figure than John Gay, author of arguably the first modern English musical, The Beggar's Opera, is a time traveller. He has 'swallowed a drug for a wager', which it was claimed, 'could make a man sleep for two hundred years' ${ }^{8}$ He has slept through time from the eighteenth century to the twentieth, a Rip van Winkle-like doze which, according to some historiographies, means that the stage John Gay has managed to skip most of the modern.

Gay now figures in a 1923 musical as a mediator, someone deeply puzzled by contemporary London and quietly nostalgic for the past. Change is measured in terms of modern dance culture which Gay interprets as a metaphor not only for a lost age, but also for lost values. Faced with the foxtrot, he despairs. 'In my day', he moans, 'we danced with grace and dignity'. From this point on, the stage is set for negotiation between an elegant past and a dissipated, if vibrant, present. Somewhat oddly, without any serious rationale at first look, the figure of 'old Gay' operates as a link, serving to reconcile 'the progress of...modern civilisation...motor cars, aeroplanes, wireless' with the tradition and continuity of British culture, figured here by Gay himself and his most famous creation, The Beggar's Opera. ${ }^{9}$

In the interim, before a kind of resolution is achieved at the show's end, there is what might appear to be a diversion, an interpolation which seems to have little 
bearing on the above narrative and sees the temporary withdrawal of old Gay into an implied audience where he watches a play within a play. After a very brief New York interlude, the second half of Dover Street to Dixie moves quite literally into another world. The show becomes a festival of contemporary dance and music as performed by some of the most celebrated black artists of the day, which is what the audience and reviewers had really come to see. ${ }^{10}$

Outside the music and dance, however, the travelling section of the show is not framed in terms of modernity at all. On the contrary, the 'Dixie' section brings America to the London stage in a Southern guise. Far from representing modern, cosmopolitan, culture, Dixie presents a rural idyll, reproducing a Southern homeland where audience and play characters alike are reassured by reunion with a familiar stereotype, 'Coal Black Mammy/Coal Black Mammy once more'. Ironically enough given the reputation for vitality, scandal and the racialised controversies surrounding the show, African-American music and dance are reproduced here in the context of a curiously static spectacle, set outside narrative development. Under a double disguise of minstrelsy, the black part of Dover Street to Dixie, so up-to-date in terms of sound and movement, is confined in a mise en scène that simply fails to register in terms of any version of contemporaneity at all.

Of course revue was notoriously idiosyncratic in its characteristic juxtapositions. In this genre, it was quite usual for a 'sylvan ballet' to follow a satirical sketch or an opera parody. But Dover Street to Dixie was not formulated in that way. This show of linked halves and migrating sections was emphatically structured around difference, antithesis even-tradition/innovation; age/youth; London/New York (Dixie?); English/American. With its 'white' and 'black' halves the play was also deeply imbricated in the politics of race and Otherness, drawing an 
audience attracted not least by the assumed exoticism of the Dixie section. Far from being a random collection of materials, Dover Street to Dixie was explicitly formulated out of these contrasting elements, worked in terms of their relation to each other. In this respect it represented a very particular, highly mediated version of cultural exchange, taking place across a number of controversial and potentially destabilising borders and checkpoints. What were the contexts producing this strange concoction which strained so hard at its own seams-if not for coherence, then, at least, for some kind of imagined containment?

\section{'Winning them over' - jazz, modernity and sailors' riots}

The West End had already been greatly influenced by an Atlantic cultural transfer that brought a wide range of American acts, styles and performers to Britain some years before 1923. ${ }^{11}$ Revues like Hullo Ragtime (1912), Everybody's Doing It (1912), Way Back to Darkey Land (1913) and the Wild West revue While You Wait (1913) marked America's growing influence on the West End musical theatre stage, a development that continued during the war with, among other shows, the transferred Irving Berlin revue Watch Your Step (1915). In wartime Britain and beyond, American popular music and dance were moving into the void left by an ostracised German music and theatre culture. Imported American acts such as the Original Dixieland Jazz Band appeared in the revue Joybells (1919), while Paul Whiteman (often billed as the 'King of Jazz') and his orchestra featured in Brighter London (1923). The adaptation of the American 'jazzaganza' You'd Be Surprised (1923) played at the Covent Garden Opera House, which often headlined jazz music and dancing. Other American bands, the Southern Syncopated Orchestra, for example, 'the first Afro-American Jazz 
orchestra to make a substantial public impact in the United Kingdom', toured extensively around Britain and Europe popularising the new music. ${ }^{12}$

At the same time, the self-contained hit tune became a major element of the song and dance musical, and New York vaudeville and revue the central vehicles in which hit tunes were created. Here songs 'calculated to appeal to the public' were interpolated with 'no particular, if any, relation to the musical's plot or character'. Indeed, the 1920s were a golden age for the Tin-pan Alley song, 'the song with the widest commercial appeal (the hit)'. Combining 'commerce and showbiz', New York overtook the old European centres of Vienna, London, Berlin and Paris in these years, becoming the new dominant musical theatre metropolis, with American musical theatre and the music-recording industry developing in 'symbiotic relationship with one another. ${ }^{13}$

African-American dance and music were of central importance to the spread and authority of the American musical. All-black shows like Clorindy (1898), In Dahomey (1905), Darktown Follies (1913) and Shuffle Along (1921) had demonstrated on Broadway 'the potential of the negro syncopated music' and set the 'trend toward the adoption of anything black-and particularly of Afro-American dance'. ${ }^{14}$ The trans-Atlantic route for this trade was opened up with In Dahomey, famously performed in London before Edward VII in 1906.

But the travel of black American culture into the mainstream went well beyond such genre pieces. The new technology of the radio and gramophone, along with the growing number of record manufacturers, helped establish jazz as the zeitgeist soundtrack of the age, reinvigorating a listless and tired post-war British culture. ${ }^{15}$ In London and across the Continent, dances like the Texas Tommy, the 
Bunny Hug, the Monkey Hug, the Lame Duck, the Black Bottom, the Fox Trot, the Cake Walk and the Charleston became the newest things in social dance.

Such cultural processes of transfer, both assimilative and appropriative, out reached the single show and were hardly straightforward, neutral or benign. A show like Dover Street to Dixie was crucially framed by the problematics of reconciling a fashion-conscious embracing of jazz music and dance with the panic of Wyndham Lewis's 'paleface' West. ${ }^{16}$ Its appropriation of an 'expressive vitality...[used] to make the song-and-dance musical truly modern', simultaneously negotiated the fact that, for many, jazz was an unwelcome and dangerous innovation. ${ }^{17}$ The 'wild' and 'primitive' associations, so much loved by the European intelligentsia, became connected in the minds of a more conventional bourgeoisie with every kind of disturbance to civilised calm, from 'unpredictable, fragmented excitement...to antisocial behaviour.' ${ }^{18}$ The racialised dimensions to this dynamic were obvious and always threatening the boundaries of 'safe pleasure' which the text and performance of popular musical theatre attempted to define. From this perspective, in Britain as in America, specific 'backgrounds' of contemporary racial conflict, while not directly addressed, informed a show like Dover Street to Dixie and its cultural reception.

There had been a long history of African-American acts and performers in the West End, but their presence at this precise juncture coincided with social unrest brought about by national and racial tensions across Europe and America. In Britain race riots took place as white and black sailors fought over jobs in 'Glasgow, South Shields, Salford, Hull, London, Liverpool, Newport, Cardiff and Barry between January and August 1919. Further sporadic rioting took place in 1920 and 1921. Five people were killed, dozens injured and at least 250 arrested' ${ }^{19}$ Various interpretations of national identity emerged from metropolitan and colonial opinion in relation to 
these disturbances. The standard response, however, expressed narrow versions of patriotism and put 'Britishers first' ${ }^{20}$ In the press, the inclusion of high profile African-American performers and musicians on the West End stage in revues like The Rainbow and Dover Street to Dixie was constructed in terms of the seaport troubles, another early example of 'blacks taking white jobs'.

Black performers contracted to work on the former show had been refused work permits in March 1923. Earlier, in October 1922, the John Bull, a right-wing scandal sheet, had run a campaign against a touring black theatrical troupe, Will Garland's Coloured Society, claiming they would be the cause of 'scandal and impropriety'. Finding no evidence for such a claim, the Home Office gave the troupe authorisation, but only on a limited basis for six weeks and with the justification that this was 'a specialty act for which Britons could not be substituted'. ${ }^{21}$ When the news broke of Cochran's plans to bring a plantation revue over to the 'centre of the world', as the Pavilion signposted itself, where 'black artistes would actually mix with white folks at tables', a small storm broke out. ${ }^{22}$ Hannen Swaffer, writing in the Daily Graphic and the Times (both London), wrote an 'exposé' of 'the Scandal of Negro Revues'. 'While the actors and actresses of England', he wrote, 'are concerned about their bread and butter...Sir Alfred Butt and C.B. Cochran are quarrelling apparently about which niggers they have got.' Producing a lengthy list of out-of-work performers, Swaffer concluded with a series of rhetorical questions, 'If good revue artistes are wanted, why is Nelson Keys not working now? And why is Daphne Pollard not in a show?'23

Such vitriol went well beyond employment issues. It exposed deep racisms and powerful insecurities about Britain's place in the world. Just as the black presence in the seaports riots challenged 'the legitimacy of Britain's imperial rule and raised 
questions about the identity and status of colonial peoples both within the metropolis and in the colonies', so black performers on the West End stage, exotic, attractive and very much the 'newest thing', were a challenge to a white, West End entertainment culture that had dominated since the $1890 \mathrm{~s}^{24}$

C. B. Cochran famously removed Hannen Swaffer from his seat in the stalls on the opening night of Dover Street to Dixie. He shared Florence Mill's concerns about 'the possibility of racial demonstrations'. According to theatre history legend, 'the tension was palpable', until, that is, Mills herself took the stage, at which point a mesmerising calm apparently descended. The plantation revue had started with 'spirited music from the Plantation Orchestra, then the chorus entered dancing frantically, followed by a statuesque blues singer, Edith Wilson, singing the blues'. Mills, however,

knew a jazzy din would not protect her entry. Her opening number was the soft, dreamy music of 'Down among the Sleepy Hills of Ten-Ten-Tennessee'. She would occupy the stage alone, dressed in the ragged costume of a pathetic plantation boy carrying a hobo's bundle.... There was a hush as the audience got its first glance of the tiny Black figure that had attracted so much attention. Florence's sweet, high tones spread through the theatre as she sung of 'a little rest beyond the fields of golden grain...down among the hills of Ten-TenTennessee'. The people in the audience sat forward on the edge of their seats and Cochran sat back with relief. He knew she had won them over. ${ }^{25}$

Or as one reviewer put it so tellingly, 'All our prejudices against these café au lait entertainers melt when Florence Miller begins to sing. ${ }^{, 26}$ 
[CAPTION] Florence Mills and the 'Dusky Vamps' with Will Vodrey and his Orchestra. Dover Street to Dixie, 1923

\section{Cultural revivalism}

Dover Street to Dixie addressed other related insecurities, these ones usually ignored by theatre history. Its strained attempts at remaining a la mode while securing a white Anglo-Saxon trans-Atlantic modernity shared play space with more domestic concerns about how much Britain's role in the modern world was perceived to be diminishing - as it was of course. In the first part of the show, central to any serious reading of Dover Street to Dixie, there is a moment early on when Gay first hears the 'racket' of modern dance music. The lights suddenly dim. Framed by the dancing of an old fashioned minuet back stage, the old man delivers a speech about past times and declining cultural values. 'Ah madam', he asks 'what is there to look forward to?' In the midst of a confusing, chaotic contemporary world, Gay looks backward to a more innocent, elegant time when 'we danced the stately minuet accompanied only by the sweet strains of the violin'. New times culture, Gay maintains, at least at this part of the show, is nothing short of a disaster — 'grace' and 'dignity' are all gone.

The cultural nostalgia echoed contemporary politics and the articulation of a new British nationalism espoused with particular force by the Conservative leader Stanley Baldwin during the 1923 General Election. Baldwin had cultivated the persona of the English provincial country gentleman, projecting himself in terms of solid, steadying leadership in the face of vast financial debt. In response to serious and growing social disorder, Baldwinite politics advocated 'not just a politics of values, but also a politics of place and identity', where 'an indigenous tradition of English patriotism' could be underpinned by nostalgia for pastoral, the folk ideal and 
deference in a responsible social hierarchy. ${ }^{27}$ Such a politics perpetuated the myth of a syncretic English society and sought to neutralize social conflict, the product of 'working-class consciousness' constructed as a 'foreign import' ${ }^{28}$

Baldwin presented this political platform in terms of 'compromise and consensus'. It was designed to displace the old jingoism of Empire and imperialism, a discourse badly compromised by war-indeed a Victorian leftover held by many to be species of warmongering, and even responsible for war. The main continuity in his reimagining was the notion of a 'nostalgic ideal of English independence', permanent, timeless and yet adaptive to modern conditions: 'we must see to it that in some way we can preserve the character of our people to meet the changed conditions of the age, and see that our character triumphs over our environment'. Continuity with the past was to be based, not on economic power or military might, but on something more 'human' and implicitly evolutionary: ‘the old narrow nationalism and the old brazen imperialism must pass....They have played their part...our nationalism and imperialism will not die but they will change, grow more human. ${ }^{29}$

An associated discourse of political culture also began to be asserted at this time, displacing the once familiar focus on Empire and imperialism. The central idea here was of the 'commonwealth', a term which, as Philip Williamson argues, took on the force of a slogan in the early 1920s, '[masking] from... British public opinion the full impact of the retreat from great power status....This continuing notion...that Britain and its monarch remained the hub of the commonwealth was able in part to compensate for this massive loss of international prestige. ${ }^{30}$ In this way, the cut and thrust realities of Empire acquisition were displaced by a new insistence on a shared, collaborative past, underpinned not by exploitation but, rather, by cooperation in a mutual and shared enterprise. 
That version of conservatism was accompanied by a number of related ideas, reflected in various ways in Dover Street to Dixie. A persistent pastoral and rustic imaginary was prominent among conservative literati, used to define the nature and scope of the English national ideal. Ruralism served, again, as consolation for the loss of authority over the modern world, implying an idealised vision of the simple life and a 'community' that contrasted sharply with metropolitan vanities. It proselytised the virtues of ordinary life and tradition. 'The rural was above all a means of suggesting that there were ancestral voices, immemorial values, old fashioned virtues' and a common inheritance that bound the nation together. It provided an imagery which reinforced a larger theme...the importance of place and historic roots. ${ }^{31} \mathrm{~A}$ similar set of meanings surrounded the plantation idyll in Dover Street to Dixie, helping to locate the wider social world, as well as the specific nation state, in a familiar hierarchical order - although not, as we have seen, without multiple ironies.

Yet another set of contemporary discourses utilised at this time argued that the historic 'roots' of the nation were powerfully expressed in the theatre itself. Growing calls for the establishment of a British national theatre led to the first British Theatre Conference being held in Stratford-upon-Avon in 1919. It called for the 'development of Acting, Drama and the Theatre as forces in the life of the Nation'. ${ }^{32}$ A theatre movement emerged seeking to revive what many saw as a neglected British cultural heritage, devoting its energies to saving 'lost' plays. ${ }^{33}$ The repertory movement was one strand in a burgeoning theatrical culture that had a 'growing understanding of theatre's potency as an educative as well as artistic or entertainment medium and therefore of its importance in the cultural life of the country'. ${ }^{34}$ Sir Nigel Playfair, the actor-manger of the Lyric Hammersmith from 1919 to 1932, was an influential figure in the repertory theatre movement. His revival of Gay's The Beggar's Opera at the 
Lyric in 1920 was much in keeping with the idea of reclaiming British's theatrical works from the past. With its satirical lampooning of contemporary values and politics, The Beggar's Opera, a ballad opera, was in many respects a forerunner of the revue style. Playfair's revival ran for 1,468 performances and was still playing in May 1923.

Against such a background, The Beggar's Opera and its eighteenth-century author became central to a 1923 revue. ${ }^{35}$ Both were part of the contemporary context which was the proper domain of revue — as was the wider nostalgia for a lost past and the seeming alienation from a fast-changing future. But Dover Street to Dixie does not just make a passing allusion to Gay, his play and the Playfair revival. On the contrary, it makes a serious commitment to the whole idea of cultural revival, at the same time as it appears to celebrate and exemplify the new. All of which makes Gay's visit to see a performance of his own play in Dover Street, yet another play within a play scenario, of particular importance. In a moment of calm, before the potential upheaval of New York, Lady Welbeck takes the time traveller to see a modern production of his own play in London. Gay is both reassured and astonished. For all the change of the intervening years, The Beggar's Opera is still being performed and appreciated. The place of tradition and continuity seem assured. 'Can it be true that my opera is [s]till being played?' Gay asks. The question is rhetorical of course. Unsurprisingly, the pleasure of seeing this old play, central in the audience's mind to British theatre culture, heralds the crucial change of heart. Not for the last time in the show, modernity is redeemed, made safe in the present, because the past, it turns out, so shapes and informs the modern world. 'Madam, the progress of your modern civilisation astounds me. You have motor cars, aeroplanes, wireless - and The Beggar's Opera. ${ }^{36}$ 


\section{Dover Street to Dixie and the 'special relationship'}

This first half of Dover Street to Dixie, is a 'white half' but it is no gung-ho celebration of British culture. On the contrary, Britain's status in the world, as articulated here, seems marginal and fragile. To the extent that tradition and heritage mean something, Britain retains a certain cultural caché, but no more than that and only in relation to limited domains. The fact that Gay's play is not lost, cannot restore, for instance, the wealth and glamour of the traditional landed aristocracy so much missed in the play. There is little doubt here, then, that Britain no longer authorises contemporaneity. In this respect, Dover Street to Dixie, as well as seeking the new and innovative, was sharing territory with familiar issues of its day. In many ways it was highly symptomatic of a particular framing of the state of the nation question in the post-war period. Like so much of Britain's cultural output in the 1920s and 30s, Dover Street to Dixie was permeated by the sense that times had moved on, irrevocably.

Again there were local and quite immediate dimensions here that had particular relevance for the play. America's ascendancy was obvious and registered in all sorts of ways, not least in terms of the popular culture everywhere invoked in Dover Street to Dixie. Shifting roles in international relations post First World War, however, formed the 'serious' ground where seismic shifts in international power structures may have been felt most profoundly. Its entry into the Great War in 1917, not as 'an ally but an associate power', on clearly negotiated terms, was one of many indicators pointing towards America's new significance in international agendas, in Europe as in the Caribbean and South America. ${ }^{37}$ Coming to the military and economic aid of an exhausted and weakened Europe had confirmed its increasingly 
unassailable position in the world. It had made huge loans to finance the allies' war expenditure and Britain had incurred huge debts. The USA was its major creditor; it owed $\$ 4.6$ billion ( $£ 920$ million). This was tangible expression of a changed world order, for 'debts touched the basic question of...who would dominate the peace'. As Robert Self argues, 'few issues more pungently demonstrate the complex nature of this profoundly ambivalent relationship...than the vexed question of British war debt to the United States. ${ }^{38}$ In December of 1922, the Chancellor of the Exchequer, Stanley Baldwin, and the Governor of the Bank of England, Montagu Norman, made the transatlantic crossing on a 'mission to America'. ${ }^{39}$ As reported in the Times, their 'delicate task', was to try and negotiate a new repayment deal for Britain's debt. The United States 'adamantly refused to consider readjustment', a refusal that was to have long-lasting effects socially and politically for a Britain now forced to re-situate itself in light of a substantial shift in power and status. ${ }^{40}$

Against this background, Dover Street to Dixie mounted an alternative version of Britain/America, staged-managed to restore partnership on equal terms to AngloAmerican relations. It was a fantasy treatment, nothing less than an exhuberant exercise in face saving that permeated the structure of the show as an overarching narratology. Thus at the beginning of Act 2, after the insecurities of Act 1, the two great cities, London and New York, are represented on either side of the stage. Two characters cross from either side. They meet in the middle and the following exchange takes place:

Silas: Say -you're English, ain't you?

Joshua: I guess so

Silas: What?

Joshua: I mean not 'arf. 
Silas: Waal—I'm an American.

Joshua: You astonish me.

Silas: Put it there (clasp hands)

Joshua: Ah! Hands across the sea! ${ }^{41}$

At first sight, the encounter seems confused. There is initial misunderstanding, although this arises not so much from real differences as opposed to expected ones. Once the Englishman, Joshua, sounds like the stereotype, he is immediately recognised. By the end of the short exchange, the two men accept in each other something approaching a familial connection. A 'special relationship' is formed:

We're getting closer everyday,

From England to America to America to-day.

From England to America,

Is just across the way.

There's Yankee Doodle I can hear,

And Rule Britannia, and Johnny Get your Gun

We're both so close together now

By the end of the show, the sort of transformation that can only happen in musical theatre has taken place. Old Gay has become thoroughly reconciled to the New World. He knows the dance steps and talks the talk, and his hometown London has become that much smaller as a result. 'I've been over to Amurrica', he exclaims 'and I guess I can shake a leg with any gol darn guy in this one hoss li'l' ole town called London'. While the arcadia-like fantasy of the plantation revue has been taking place, a miracle has occurred. The Anglo-Saxon contract has been renewed, albeit in a reverse style and imaged in this extraordinary show by the author of The Beggar's Opera becoming thoroughly assimilated into new times culture as a Yankee! 


\section{Across Europe-reimagining Atlantic crossing}

The public transcript of black performance in Dixie, framed by some very British obsessions, was seemingly complicit in its own subordination. The plantation revue exploited vitalist myths propagandised across a range of twentieth-century cultures from fin de siècle modernism to the Harlem Renaissance. At same time it was specifically arranged as a display of blackness made safe, a different kind of consumer product characterised not by strength and sexuality, but by a further set of stereotypes and their associated markers-plantations, banjos, lamentation ('I can hear the Whip-poor-will callin/To me from the hill, ain't no wonder/That I'm feeling lonely, I can see the/ Waving corn wavin' howdy every morn'). With songs like 'He May be your man but he comes to see me some time', the song and dance of revue denoted fast times on the darker edges of behaviour. But the coding of the sociogeographic in the plantation revue in Dover Street to Dixie evoked a different world, suggestive of nineteenth-century minstrelsy and blackface.

Of course the dynamics between audience, performer and performance would have been complex and unpredictable, especially in relation to a show like Dover Street to Dixie. If in some ways the plantation revue looked back to burnt cork and seaside entertainment, the forward-looking dimensions were also entirely explicit. The presence of black performers of such status and reputation in London made Dixie part of that 'critical cosmopolitanism', deeply shaped by the 'eruption of black expressive culture and political initiatives in the 1920s'. ${ }^{42}$ When Mills arrived in London, as well as preparing for her role in the plantation revue and dealing with the intimidation of London audiences and a possible public furore, she also had immediate entrance to a diaspora of black public intellectuals that was prominent in London. During the course of the run, she met up with such figures as the Indian poet 
Mukul Day and Sol Plaatje. On May 121923 she was guest of honour at a special meeting of 'The Coterie of Friends', an organisation established by the classical composer and jazz musician Edward Thornton Jenkins to 'further intercourse among young men of colour, resident or temporarily resident in Great Britain; to provide its members with a library including books and papers relating to people of colour' ${ }^{43}$ Vodery, the composers and musicians Shelton Brooks and James P. Johnson and the West Indian cricket team, were also guests. Ridiculed by Swaffer as 'the Negroes Jubilee', the event was, according to Mill's biographer, 'an opportunity for Mills to catch up with gossip on the local scene, especially the race issues' ${ }^{44}$

In spite of its return to the plantation, this was a border crossing show and raised further possibilities of movement across other boundaries, not all of them circumscribed by the immediate play text. Notwithstanding the stereotypes of the Dixie revue, the show evoked the agency of African-American and other black performers touring across European centres. As bell hooks argues, such movements inevitably involved 'the disruption of the colonized/colonizer mind-set'. hooks continues, 'wherever Africa Americans created music, dance, poetry, and theatre it was regarded as testimony, bearing witness, challenging racist thinking which suggested that black folks were not fully human, were uncivilized.' ${ }^{45}$

For all the dubious instincts and insecurities embedded in the show and its determination to put black performance in a safe place, the Dixie actors, actresses, dancers and musicians, had nevertheless made the transfer from the margins to the mainstream, 'disturbing', as W.E.B. Dubois has it, 'the conventional, acceptable politics of representation. ${ }^{46}$ Certainly the show's audiences were presented with a binary relationship, but it was a confused, ambiguous one. The demarcation between modernity and black America suspended in a non-threatening rural idyll, clear as it 
was, also constituted a blurring of the lines. In a very real sense, African-American music and dance was bursting through the barricades. Performers like Mills and Vodery had returned the Atlantic crossing, bringing to Europe, with all the usual provisos, the idea that contemporary popular culture at its most exciting was AfricanAmerican.

In that sense the reverse Atlantic crossing was in the process of becoming reinvented as a new, more human, world, with startling effects on more liberalised Continental stages. Here the 'Negro vogue' referred to by Langston Hughes was in full swing, as black acts performed across Europe. In Berlin Will Garland's 'NegerGesangs-Quinett' (Negro-Quintet) recorded four titles for the Vox company in 1924, whilst the 'Chocolate Kiddies' were playing Duke Ellington's music in their revue at the Admiralpalast in 1925. Berlin was also where the American choreographer and performer Louis Douglas formed a troupe called Black People with key members from the disbanded La Revue Negré starring Josephine Baker. Baker had staged her most iconic performance, 'the Dance of the Savages' performed in nothing more than a loin cloth and the infamous banana skirt dance on her extensive European tour. For many intellectuals of this period black performances like these 'functioned as the original, incomplete germ of humanity against which the modern [white] European could measure, humanize, or culturally regenerate himself. ${ }^{47}$ In that sense the idea of the 'primitive' passed over into popular culture becoming the new modern. Black performance generally signified on an even wider basis, registering an impact that turned Hegelian raciologies on their head. In a transference that cut both ways, these erotic routines handed back the stereotypes in comic, playful form that ironically marked the promise of temporary release from the modern world. Black transcultural performances along with the 'colours' and 'rhythms' of jazz, were 'inextricably 
interrelated' with modernism; constructed as both modern and primitive, embodying, as Sieglinde Lemke argues a 'primitivist modernism'48. This was the ultimate return for American-Africans expressing the complexity of transatlantic modernism, 'exploiting the spurious racialisms of their time as well as enabling a space for satirical comment on the absurdity of such depictions. ${ }^{49}$

\section{Notes}

${ }^{1}$ Langston Hughes, The Big Sea (New York: Hill and Wang, 1940), 223.

${ }^{2}$ The six shows were Anna Christie, Partners Again, Little Nelly Kelly, The Music Box Revue and So this is London. Cochran was at the same time presenting plays by the avant-garde French playwright Sacha Guitry and a series of matinees starring Elenora Duse.

${ }^{3}$ Bill Egan, Florence Mills, Harlem Queen (Lanham, MD: Scarecrow, 2004), 82.

${ }^{4}$ Morris Harvey, Harold Simpson, Lauri Wylie, Dover Street to Dixie (British Library: Lord Chamberlains Plays, 1923).

${ }^{5}$ Cathy Ross, Twenties London: A City in the Jazz Age (London: Philip Wilson, 2003), 35 .

${ }^{6}$ Harvey, Simpson, Wylie, Dover Street to Dixie.

${ }^{7}$ The night watchman mistakes, or feigns to mistake, Lady Walbeck for a prostitute: ‘ 'Ere- you'd better 'op it. My old woman'll be ere in a minute with my breakfast.'

${ }^{8}$ Harvey, Simpson, Wylie, Dover Street to Dixie.

${ }^{9}$ Dover Street to Dixie.

${ }^{10}$ The Times found the first half of the show 'a little dreary'. Mills 'in particular, is endowed with a great deal of personality, but all the members of the company work as 
though each was its principal and this, perhaps, is the secret of their success'. The Times,

${ }^{11}$ See Dominique-René de Lerma, 'Black Composers in Europe: A Works List', Black Music Research Journal, 10 (1990), 275-334; Rainer Lotz and Ian Pegg (eds), Under the Imperial Carpet: Essays in Black History 1780-1950 (Crawley: Rabbit Press, 1986); Clarkson Rose, Beside the Seaside (London: Museum Press, 1960), 59-83; Thomas L. Riis, 'The Experience and Impact of Black Entertainers in England, 1895-1920', American Music, 4 (1986), 50-8; Rainer E. Lotz, 'The Black Troubadours: Black Entertainers in Europe, 1896-1915', Black Music Research Journal, 10 (1990), 253-73. Howard Rye and Jeffrey Green, 'Black Musical Internationalism in England in the 1920s', Black Music Research Journal, 15, (1995), 93107.

${ }^{12}$ Howard Rye, 'The Southern Syncopated Orchestra' in Rainer Lotz and Ian Pegg (eds), Under the Imperial Carpet, Essays in Black History 1780-1950 (Crawley: Rabbit Press, 1986), 216.

${ }^{13}$ David Walsh and Len Platt, Musical Theater and American Culture (London: Praeger, 2003), 73-74.

${ }^{14}$ Lynne Fauley Emery, Black Dance in the United States from 1619 to 1970,

(London: Dance, 1980), 210, 223

${ }^{15}$ In 1912 there were 3 record manufacturers in Britain; by 1916 there were 60.

${ }^{16}$ See Wyndham Lewis, Paleface: The Philosophy of the 'Melting Pot' (London:

Chatto and Windus, 1929).

${ }^{17}$ Walsh and Platt, Musical Theater, 111.

${ }^{18}$ Ross, Twenties London, 27.

${ }^{19}$ Jacqueline Jenkinson, Black 1919: Riots Racism and Resistance in Imperial Britain (Liverpool: Liverpool University Press, 2009), 1. 
${ }^{20}$ Jenkinson, Black 1919, 4.

${ }^{21}$ See Egan, Florence Mills, 81.

${ }^{22}$ Daily Graphic, 6 March 1923.

${ }^{23}$ Hannen Swaffer, ‘The Scandal of Negro Revues', Daily Graphic, 5 March 1923.

${ }^{24}$ Jenkinson, Black 1919, 3.

${ }^{25}$ Egan, Florence Mills, 87.

${ }^{26}$ Sketch Magazine, 13 June 1923

27 Philip Williamson, Stanley Baldwin (Cambridge: Cambridge University Press, 1999), 243; Paul B. Rich, Prospero's Return: Historical Essays on Race, Culture, and British Society (London: Hansib 1994), 31.

${ }^{28}$ Williamson, Stanley Baldwin, 257.

${ }^{29}$ Rich, Prospero’s Return, 36, 30.

${ }^{30}$ Williamson, Stanley Baldwin, 8, 9.

${ }^{31}$ Stanley Baldwin, 249.

${ }^{32}$ Clive Barker and Maggie B. Gale (eds), British Theatre between the Wars, 1918-1939 (Cambridge: Cambridge University Press, 2000), 15.

${ }^{33}$ The Phoenix Society, an offshoot of the Stage Society, the British Drama league and the Workers' Educational Association were all key players in this movement. It was supported by such figures as T. S. Eliot and William Poel.

${ }^{34}$ George Rowell and Anthony Jackson, The Repertory Movement: A History of Regional Theatre in Britain (Cambridge: Cambridge University Press, 1984), 2. ${ }^{35}$ Playfair's production also had an influence on the development of Brecht's The Threepenny Opera. Brecht knew the play through Elizabeth Hauptmann's German translation, which she worked on after hearing about the Playfair revival in London. 
See Stephen McNeff, 'The Threepenny Opera', The Cambridge Companion to Brecht (Cambridge: Cambridge University Press, 2006), 81.

${ }^{36}$ Harvey, Simpson, Wylie, Dover Street to Dixie.

37 Robert Self, Britain, America and the War Debt Controversy: The Economic Diplomacy of an UnSpecial Relationship, 1917-1945 (London: Routledge, 2006), 4. United States international political domination was manifest at various international conferences: the Paris Peace Conference, The League of Nations, the Washington Naval Conference (1921-2).

${ }^{38}$ Self, Britain, America and the War Debt, 15, 16, 13.

39 'The Mission To America. Mr. Baldwin And His Colleague. A Delicate Task', The Times, 27 Dec 1922, 10.

${ }^{40}$ Self, 'Britain, America and the War Debt', 14.

${ }^{41}$ Harvey, Simpson, Wylie, Dover Street to Dixie.

${ }^{42}$ Brent Hayes Edwards, The Practice of Diaspora, Literature, Translation, and the Rise of Black Internationalism (Cambridge, MA: Harvard University Press, 2003), 3. See also Laura Doyle, 'Atlantic modernism at the crossing: the migrant labours of Hurston, Mckay and the diasporic text' in Len Platt (ed.), Modernism and Race (Cambridge: Cambridge University Press, 2011), 116-36 and Brent Hayes Edwards, The Practice of Diaspora, Literature, Translation, and the Rise of Black Internationalism, (Cambridge, MA: Harvard University Press, 2003).

${ }^{43}$ Jeffrey P. Green, Edmund Thornton Jenkins (Westport, Conn.: Greenwood, 1982), 126.

${ }^{44}$ Egan, Florence Mills, 86.

${ }^{45}$ bell hooks, Outlaw Culture: Resisting Representations (London: Routledge, 1994), 5.

${ }^{46}$ hooks, Outlaw Culture, 5. 
47 Heike Raphael-Hernandez (ed.), Blackening Europe, The African American Presence (London: Routledge, 2004), 37.

${ }^{48}$ See Sieglinde Lemke, Primitivist Modernism, Black Culture and the Origins of Transatlantic Modernism (Oxford: Oxford University Press, 1998).

49 Jayna Brown, Babylon Girls, Black Women Performers and the shaping of the Modern (Durham and London: Duke University Press, 2008), 6. 